\title{
Nurse effect in seedling establishment: facilitation and tolerance to damage in the Andes of central Chile
}

\author{
Efecto nodriza en el establecimiento de plántulas: facilitación y tolerancia al daño \\ en los Andes de Chile central
}

\author{
IAN S. ACUÑA-RODRÍGUEZ ${ }^{1}$, LOHENGRIN A. CAVIERES ${ }^{1,2} \&$ ERNESTO GIANOLI $^{1}{ }^{*}$ \\ ${ }^{1}$ Departamento de Botánica, Universidad de Concepción, Casilla 160-C, Concepción, Chile \\ ${ }^{2}$ Instituto de Ecología y Biodiversidad, Casilla 653, Santiago, Chile; \\ *e-mail for correspondence: egianoli@udec.cl
}

\begin{abstract}
Nurse effects, which occur when one plant species enhances the survival or growth of another plant species, are predicted to be most relevant in stressful environments. These effects are particulary important during seedling establishment due to their vulnerability to both biotic and abiotic factors, such as herbivory and drought. Tolerance to herbivory reflects the degree to which plants are able to regrow and reproduce after damage, and should vary with resource availability. In the high Andes of central Chile, the cushion plant Laretia acaulis (Apiaceae) acts as a buffer against environmental stress, enhancing survival of several associated plant species. We hypothesized that tolerance to herbivory of seedlings growing inside the canopy of L. acaulis should be greater than that of seedlings growing outside the cushion plant. We conducted a field experiment to test this hypothesis for two native perennial species in the high Andes of central Chile: Hordeum comosum (Poaceae) and Haplopappus anthylloides (Asteraceae). Seedlings of each species were planted inside and outside L. acaulis cushions and half of them received manual damage (50\% foliar tissue removed). Seedlings growing inside the nurse species showed high survival independent of the damage treatment. Whereas position (inside or outside the cushion plant) did not affect tolerance of Haplopappus anthylloides, it significantly affected tolerance of Hordeum comosum. Thus, we found similar survival of damaged and control seedlings of H. comosum inside the cushions, but survival of damaged seedlings in the bare ground was lower than that of control seedlings. We verified the occurrence of nurse effects of Laretia acaulis on the establishment of both species, and detected enhancement of tolerance to damage in Hordeum comosum in this stressful habitat.
\end{abstract}

Key words: facilitation, Laretia acaulis, herbivory, tolerance, nurse effect.

\section{RESUMEN}

Se ha sugerido que el efecto nodriza, el cual se evidencia cuando una especie vegetal incrementa la supervivencia o el crecimiento de otra, es más relevante en ambientes estresantes. Este efecto sería particularmente importante durante el periodo de establecimiento de las plántulas debido a su alta vulnerabilidad a factores bióticos y abióticos como herbivoría y desecación. La tolerancia a la herbivoría evidencia la capacidad de las plantas de recrecer y reproducirse después del daño, pero esta capacidad es recurso-dependiente. En los Andes de Chile central, la planta en cojín Laretia acaulis (Apiaceae) atenúa el efecto del estrés ambiental, aumentando la supervivencia de diversas especies de plantas asociadas. Proponemos que las plántulas que se encuentren creciendo dentro de los cojines de L. acaulis deberían evidenciar niveles mayores de tolerancia en relación a aquellas plántulas creciendo fuera de los cojines. Para probar esta hipótesis se llevó a cabo un experimento de campo con dos especies nativas perennes: Hordeum comosum (Poaceae) y Haplopappus anthylloides (Asteraceae). Plántulas de ambas especies fueron sembradas dentro y fuera de los cojines de $L$. acaulis, y la mitad de ellas recibieron daño manual (50\% tejido foliar removido). En general, las plántulas que se encontraron creciendo dentro del cojín evidenciaron una mayor supervivencia independientemente del tratamiento de daño. A pesar de que la ubicación de las plántulas no afectó la respuesta en tolerancia por parte de $H$. anthylloides, sí afectó significativamente la tolerancia de $H$. comosum. Por lo tanto, encontramos valores similares para la supervivencia de plántulas de $H$. comosum dentro de los cojines, pero la supervivencia de plántulas dañadas fuera de los cojines fue significativamente menor que la de plántulas control. Se pudo evidenciar la ocurrencia de efecto nodriza por parte de L. acaulis sobre el establecimiento de ambas especies y conjuntamente un aumento en la tolerancia al daño para H. comosum en este hábitat estresante.

Palabras clave: facilitación, herbivoría, tolerancia, Laretia acaulis, efecto nodriza. 


\section{INTRODUCTION}

Positive interactions among plants occur when one plant species enhances the survival, growth or reproduction of another plant species (Callaway 1995, Callaway \& Pugnaire 1999). These interactions have received special attention in recent years (Bruno et al. 2003, Lortie et al. 2004) and have been reported in several ecosystems (Callaway 1995, Callaway \& Pugnaire 1999, Rand 2004), although they are particularly frequent in stressful habitats (Bertness \& Callaway 1994, Callaway \& Walker 1997, Brooker \& Callaghan 1998). Positive interactions can occur through different mechanisms, involving both environmental conditions and biological interactions (Callaway 1995), and their magnitude varies through time and space (Choler et al. 2001, Pugnaire \& Luque 2001, Callaway et al. 2002, Maestre et al. 2003). Nurse effect is a particular kind of positive interaction where one species (the nurse) provides microclimatic conditions that enhance the establishment of other (beneficiary) species (Franco \& Nobel 1988, 1989). Because of the high vulnerability of seedlings to stressful conditions (Ibáñez \& Shupp 2001), the nurse species may enhance seedling establishment via stress amelioration, which can be understood as an improvement of the environmental conditions experienced by the seedlings. This improvement can be achieved by the interaction of two mechanisms: the attenuation of some negative environmental factors such as herbivory, extreme temperatures or high solar irradiation, or by the increase of resource availability beneath the nurse species (Callaway 1995, Shumway 2000, GómezAparicio et al. 2004).

Several studies have demonstrated the negative effect of herbivory on plant fitness (Strauss 1991, Hulme 1996, Harms \& Dalling 1997, Thompson et al. 2003). Consequently, any interaction between plant species that minimizes the negative effects of herbivory, at least for one species, will fall into the definition of positive interactions (Callaway \& Pugnaire 1999). This interaction could act through physical protection from herbivores, or via the enhancement of plant tolerance. Plant tolerance to herbivory has been defined as the ability to reduce the impact of damage on plant fitness (Strauss \& Agrawal 1999, Tiffin \& Inouye 2000). The maintenance of plant fitness after herbivory implies the enhancement of physiological functions in the remanent tissue (Nabeshima et al. 2001). Tolerance mechanisms include resource reallocation, increased photosynthetic rates, and increased meristem activity (Anderson \& Briske 1995, Thompson et al. 2003). Therefore, tolerance to herbivory is a resource-dependent trait (Agrawal et al. 1999). Given that nurse species provide less stressful microhabitats inside or beneath their canopy in comparison with the surrounding environment, it is conceivable that this positive interaction may increase tolerance to herbivory.

The high Andes of central Chile are a potentially stressful environment. This ecosystem exhibits harsh winds and low temperatures during most of the year. At 2,800 $\mathrm{m}$ the soil is free of snow cover just a few months per year, presents low water availability and nutrient content (Cavieres et al. 1998), and a substantial microclimatic decoupling between bare ground and cushion surfaces (Cavieres et al. 2005). Stress levels in this ecosystem are buffered, at least in part, by the cushion plant Laretia acaulis (Cav.) Gill \& Hook (Apiaceae). Cavieres et al. (1998, 2006) have proven this for the superficial air and soil temperatures, soil hydric content and soil nutrient concentrations. In this ecosystem, the cushion species L. acaulis facilitates the growth of at least nine plant species at the same altitude (Cavieres et al. 2006). These species were more frequently found (in some cases, exclusively) inside the cushion plant than on bare ground away from cushions (Cavieres et al. 2006). On the other hand, grazing by livestock is common during plant growth season in this habitat. The present study evaluates whether positive interactions at the high Andes of central Chile can be mediated by the enhancement of plant tolerance to damage. For this, we conducted a field experiment involving simulated herbivory. The study system was composed of the cushion plant $L$. acaulis, the "nurse species", and two native perennial species: Hordeum comosum J. Presl. (Poaceae) and Haplopappus anthylloides Meyen \& Walp (Asteraceae). 


\section{MATERIAL AND METHODS}

\section{Study site}

This study was carried out at La Parva $\left(33^{\circ} 20^{\prime}\right.$ $\left.\mathrm{S}, 70^{\circ} 21^{\prime} \mathrm{W}\right), 70 \mathrm{~km} \mathrm{E}$ from the city of Santiago, in central Chile. The study site was located at $2,800 \mathrm{~m}$ of altitude in a $\mathrm{SW}$-facing slope. Climate is alpine with influence of the Mediterranean-type climate of lowlands. The mean annual temperature is $5.4{ }^{\circ} \mathrm{C}$, with a summer mean of $10{ }^{\circ} \mathrm{C}$ (Cavieres \& Arroyo 1999). Mean annual precipitation is $400-900$ $\mathrm{mm}$, mainly occurring during winter, and showing high interannual fluctuations (Santibáñez \& Uribe 1990). A high proportion of the precipitations falls as snow usually from April-May to October-November, and snow storms may occur even during the normally dry summer (December-March) (Di Castri \& Hajek 1976). According to Cavieres et al. (2000), the study site belongs to the lower Andean belt, which is located between 2,600 and 3,400 m of altitude, showing in this range two dominance peaks of cushion species. The first peak is located at 2,700-2,900 $\mathrm{m}$ and corresponds to Laretia cushions. Individual cushions are randomly distributed and their size ranges from 10 to $>150 \mathrm{~cm}$, being more frequent cushions above $1 \mathrm{~m}$ diameter (Armesto et al. 1980). At $2,800 \mathrm{~m}$ Laretia acaulis cushions reach a relative cover of $27.3 \%$ from a total vegetation cover of 40-50\% (Cavieres et al. 2000). Other herbaceous species present are: Senecio pentaphyllus, Hordeum comosum, Haplopappus anthylloides, and Hypochaeris tenuifolia (Cavieres et al. 2000).

\section{Experimental design}

To evaluate the effect of Laretia acaulis cushions on the tolerance to damage of $H$. comosum and $H$. anthylloides, we performed a field experiment aimed to evaluate seedling survival during the first growing season, which has been suggested to be the main bottleneck in seedling survival in alpine habitats (Forbis 2003). Damage (see below) was applied to experimental seedlings planted within the cushion species and on bare ground away from cushions. Seedlings were obtained from seeds collected from 120-150 individuals in the study site during the previous growing season. They were germinated in laboratory growth chambers under controlled conditions $\left(22{ }^{\circ} \mathrm{C}\right.$ and $16 / 8 \mathrm{~h}$ photoperiod), and were 2.5 month old at the planting date. From the total seedling set, we selected seedlings that had at least two fully expanded leaves for Hordeum and four true leaves for Haplopappus at the planting date. At the field, we randomly chose eight Laretia acaulis cushions and eight bare ground sites (paired design) for each target species. All chosen cushions had a diameter between 1 and $1.5 \mathrm{~m}$. On January 112005,12 seedlings of each species were planted inside each selected cushion. Another pool of 12 seedlings of the same species was planted in each of eight sites selected on the bare ground next to the cushion, at a distance greater than $30 \mathrm{~cm}$. Distance between seedlings at planting was $5 \mathrm{~cm}$, which has been shown to be enough to minimize at this stage intra-specific interactions (Cavieres et al. 2006). For seedlings planted within cushions, the distance to the cushion edge was at least $30 \mathrm{~cm}$. Seedling establishment was supported by daily water addition during the first four days after planting. All seedling stands were covered with a $25 \times 35 \times 25 \mathrm{~cm}$ herbivory exclosure to avoid subsequent herbivory ("bird cage"; mesh size: $1 \mathrm{~cm}$ ). Seedlings that died during the first week were immediately replaced.

Two weeks after planting (January 26), half of the seedlings in each pool, both within and outside cushions, received manual damage. We cut $50 \%$ of the foliar tissue: half of each leaf was clipped with scissors along the mid vein. Thus, we had a factorial design: species $x$ position $\mathrm{x}$ damage. Survival of each planted seedling was recorded every two weeks during 46 days until the end of the growing season (March 8). An unusual summer snowstorm drastically reduced the number of replicates in the experiment. Just two days before applying foliar damage, an intense snowstorm killed about $40 \%$ of the experimental seedlings, particularly those planted on the bare ground. We replaced 62 seedlings of Hordeum (40 seedlings on bare ground and 22 inside the cushions) and 48 seedlings of Haplopappus (38 seedlings on bare ground and 10 seedlings inside the cushions). All replaced seedlings were part of the same original cohort of germinated individuals. Survivor seedlings and the newly replaced ones were monitored daily 
again during one week to ensure their survival. To continue with the experiment, we chose only those experimental groups (seedling pools) having at least ten seedlings: six cushions for Hordeum seedlings, five cushions for Haplopappus seedlings, and five stands on bare ground for each species.

We used differences in the mean survival (\%) between pools of control and damaged seedlings (inside and outside the cushions) to assess the ocurrence of tolerance. If Laretia acaulis is, at least in part, facilitating the establishment of Hordeum and Haplopappus seedlings via tolerance enhancement, then the differences between the survival of control and damaged seedlings should be lower inside the cushion than outside.

\section{Statistical analysis}

Survival data were statistically analyzed for each species at the microsite level. Final mean survival (\%) was used as a fitness measure. A Kruskal-Wallis ANOVA test was used to detect differences among experimental seedling pools (position and damage as factors). We used nonparametric statistics due to the non-normal distribution of field data. Within each position (cushion/bare ground), a Wilcoxon paired-test comparing final survival of control and damaged seedling pools was used to evaluate the effect of herbivory on plant fitness. Similar mean survival of damaged and control seedling pools would imply tolerance to damage. We recorded the cumulative survival proportions (Kaplan-Meier method) to describe the establishment process (Fox 1993).

\section{RESULTS}

Kruskal-Wallis ANOVA showed significant differences in survival for both species among all experimental groups (Hordeum: $\mathrm{H}_{3}=$ $17.0475, \mathrm{P}=0.0007$; Haplopappus: $\mathrm{H}_{3}=$ $12.9674, \mathrm{P}=0.0047)$. These differences are mainly consequence of the position and show the same tendency for the studied species: high survival inside Laretia cushions in comparison with the bare ground regardless of damage. Interestingly, the effect of damage was not the same for both species. The Wilcoxon pairedtest (Table 1) for Haplopappus anthilloydes found no differences in the survival of damaged and control seedlings neither inside cushions nor in the bare ground $(\mathrm{P}=1.00$ and $\mathrm{P}=0.34$, respectively). Hence, a similar tolerance to damage was detected in both substrates (Fig. 1A). For Hordeum comosum (Fig. 1B), damaged and control seedlings growing inside of Laretia acaulis cushions showed no difference in survival (i.e., tolerance occurred), but on the bare ground survival of control seedlings was higher $(\mathrm{P}=0.0431$, Wilcoxon matched-pairs test) than that of damaged seedlings. This could be evidence of nurse effect of Laretia acaulis on Hordeum seedlings via enhanced tolerance to damage.

\section{DISCUSSION}

Although Hordeum comosum and Haplopappus anthylloides had not been reported as "facilitated" species for this ecosystem in previous studies (Cavieres et al. 1998), our

TABLE 1

Wilcoxon matched paired test for Hordeum comosum and Haplopappus anthylloides mean survival values: $\mathrm{C}=$ control seedlings; $\mathrm{D}=$ damaged seedlings. Comparisons are made within each position

Prueba pareada de Wilcoxon para los valores promedio de supervivencia de Hordeum comosum y Haplopappus anthylloides: $\mathrm{C}=$ plántulas control; $\mathrm{D}=$ plántulas dañadas. Las comparaciones se realizaron entre grupos de plántulas pertenecientes a la misma posición

\begin{tabular}{|c|c|c|c|c|c|c|}
\hline \multirow[t]{2}{*}{ Species } & \multicolumn{3}{|c|}{ L. acaulis $\mathrm{C}$ versus L. acaulis $\mathrm{D}$} & \multicolumn{3}{|c|}{ Bare ground $\mathrm{C}$ versus bare ground $\mathrm{D}$} \\
\hline & Z-value & P-value & $\mathrm{n}$ & Z-value & P-value & $\mathrm{n}$ \\
\hline Hordeum comosum & 0.53 & 0.5929 & 6 & 2.02 & 0.0431 & 5 \\
\hline Haplopappus anthylloides & 0.00 & 1.0000 & 5 & 0.94 & 0.3452 & 5 \\
\hline
\end{tabular}


results indicate that seedling establishment in these species increases when they are associated with Laretia acaulis cushions. Moreover, we detected in $H$. comosum enhancement of tolerance to foliar damage for seedlings growing inside Laretia cushions (Fig. 1B). A similar, albeit not significant, trend was found for Haplopappus anthylloides seedlings (Fig. 1A). It is likely that the reduced number of replicates caused the lack of significant differences for Haplopappus test. Due to the particularly stressful conditions of the mid summer at this altitude (Cavieres et al. 2005), any experimental seedling that survives this period of the season is assumed to be established. In this way, cumulative survival proportions show the establishment trend during the growth season for all treatments (Fig. 2A and 2B). These trends show that differences became to be relevant since mid February (second half of the season), when environmental conditions probably were more stressful due to shortage of soil moisture and extremely high soil temperature (Rada et al. 1999, Cavieres et al. 2005).

The damage level used in this study (50\% of foliar damage) has been shown to affect plant fitness in several studies of tolerance to herbivory (Welter \& Steggall 1993, Strauss et al. 2003; but see Nowak \& Caldwell 1984). This negative effect on fitness would suggest that herbivory may magnify the consequences of experiencing a given abiotic stress (Kaitaniemi et al. 1999, Thompson et al. 2003). Until now, positive interaccions involving herbivory had been related to associational resistance (Tahvanainen \& Root 1972). Associational resistance involves decreased preference of herbivores for the target plant when it is associated with another plant species instead of isolated (Hay 1986, Hamback et al. 2000, Stiling et al. 2003; but see Hjältén \& Price 1997). It is surprising that, to our knowledge, just a single work has reported positive interactions via enhanced plant tolerance to herbivory (Rand 2004). Rand (2004) compared in a salt marsh the effect of herbivory on Atriplex patula var. hastata being spatially associated with Juncus gerardi or isolated. Attacked individuals of $A$. patula growing isolated showed $50 \%$ less survival than attacked individuals associated with J. gerardi. Consequently, the present study seems to be the first evidence of "associational tolerance" in a terrestrial ecosystem.
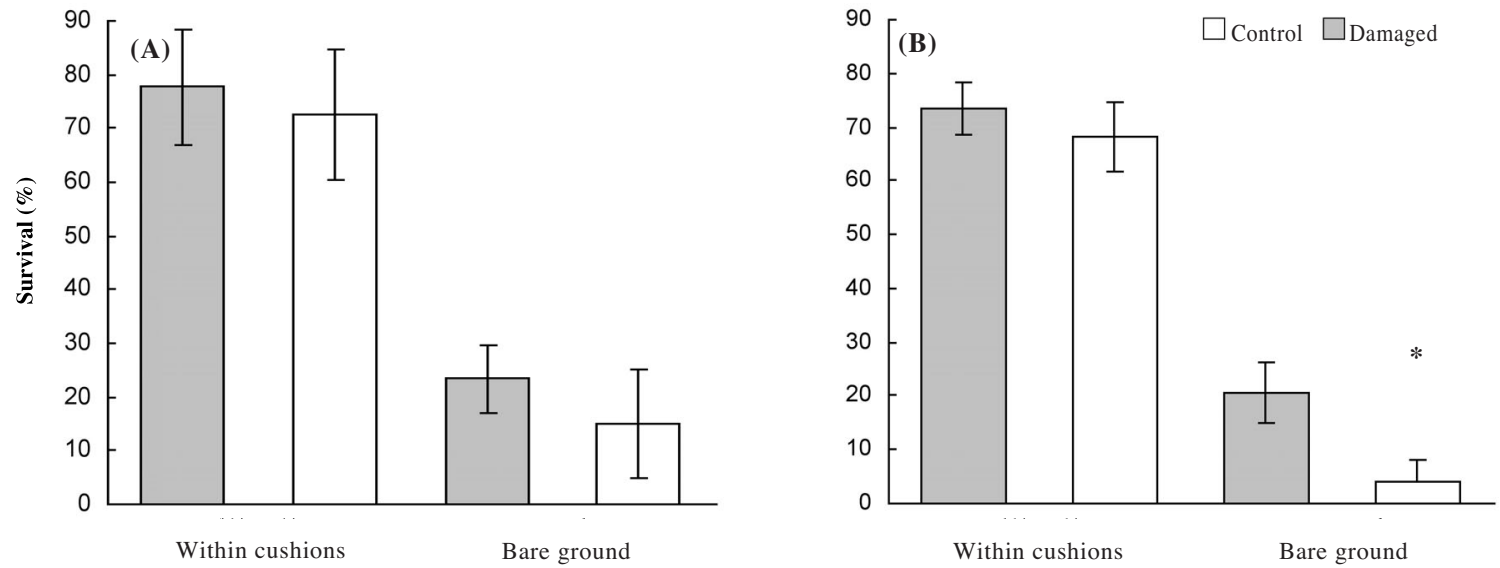

Fig. 1: Final survival average (\%) for damaged and control seedlings of (A) Haplopappus anthylloides, and (B) Hordeum comosum. Significative differences between treatmens in each position means tolerance differences. Bars represent mean survival for each treatment $\pm 1 \mathrm{SE}$; ns $=$ not significant, $* \mathrm{P}<0.05, \mathrm{n}=6-5$ cushions per bare ground stand.

Supervivencia promedio final (\%) para las plántulas experimentales (daño/control) de (A) Haplopappus anthylloides y (B) Hordeum comosum. Diferencias significativas al interior de cada posición implican diferencias en los niveles de tolerancia. Las barras representan la supervivencia promedio para cada tratamiento \pm 1 EE; ns $=$ no significativo; $* \mathrm{P}<0,05 ; \mathrm{n}=6-5$ cojines por sitio en el suelo desnudo. 

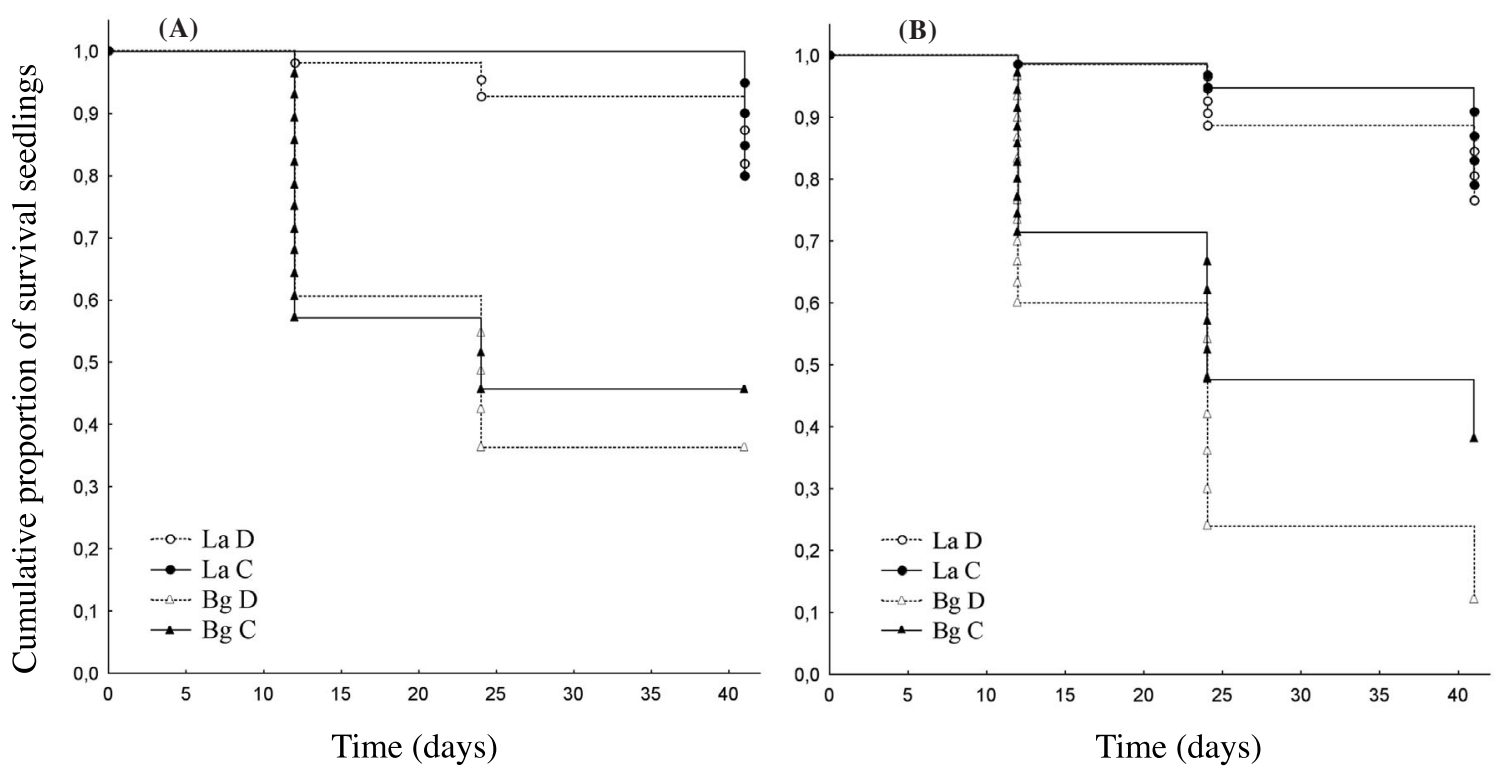

Fig. 2: Cumulative survival distributions at the individual level for experimental seedlings during the establishment process of (A) Haplopappus anthylloides, and (B) Hordeum comosum. La = Laretia acaulis, $\mathrm{Bg}=$ bare ground, $\mathrm{D}=$ damaged, $\mathrm{C}=$ control. Initial number of seedlings: $\mathrm{LaC}=$ $36, \mathrm{LaD}=36, \mathrm{BgC}=30, \mathrm{BgD}=30$ for both species.

Distribución de la supervivencia durante el periodo de establecimiento para las plántulas experimentales de (A) Haplopappus anthylloides y $(\mathrm{B})$ Hordeum comosum $. \mathrm{La}=$ Laretia acaulis, $\mathrm{Bg}=$ suelo desnudo, $\mathrm{D}=$ dañadas, $\mathrm{C}=$ control. Número inicial de plántulas: $\mathrm{LaC}=36, \mathrm{LaD}=36, \mathrm{BgC}=30, \mathrm{BgD}=30$ para ambas especies.

Tolerance implies resource costs for plants (Strauss \& Agrawal 1999) and its expression could be limited by several environmental factors (Tiffin 2000). As Cavieres et al. (2006) showed, there are significant differences at $2,800 \mathrm{~m}$ for three important soil parameters (temperature, nutrients and moisture) between the soil below the cushions and the bare ground. Cavieres et al. (2005) further suggest that even though the survival and establishment of seedlings are mediated by the interaction of several factors, at this altitude it is the water economy of the individual the critical process. Thus, it might be suggested that Laretia acaulis improved a limiting resource in the substrate, probably soil moisture (see also Cavieres et al. 1998). It has been suggested that a reduction in tolerance must only occur when lost tissue implies a decrease in plant ability to capture the limiting resource in the environment (Wise \& Abrahamson 2005). Therefore, we could suggest, at least for Hordeum comosum, that 50 $\%$ defoliation significantly affected its limitant resource acquisition rate when growing on the bare ground. Differences in survival between damaged and control Hordeum seedlings in the bare ground (Fig. 1B) support this idea.

Hordeum comosum and Haplopappus anthylloides were reported as "not facilitated species" in a previous study: both species showed no differences in their frequencies of occurence inside and outside Laretia cushions (Cavieres et al. 1998). Present results seem to suggest a different trend, at least concerning the establishment process (Fig. 2A and 2B). It is possible that facilitation became evident during this period due to the higher vulnerability of seedlings to environmental stress. As has been shown in other studies (Karban \& Thaler 1999, Rousset \& Lepart 2000), the facilitation status could vary with ontogeny and can be influenced by the stress level of the environment. We certainly know that the generality of our results is restricted by the short-term nature of this study and the small sample size. However, at least for Hordeum comosum, our results seem to be consistent with our hypothesis and its corresponding theoretical framework. Further research in this habitat is needed to understand 
the role of tolerance to herbivory in facilitation dynamics and also to determine which specific resource is involved in this process.

\section{ACKNOWLEDGEMENTS}

We wish to thank Constanza Quiroz, Marcia González, Marco Molina and, in a special way, to Liliana Zúñiga for their field assistance; Nelly Rodríguez for her advices and Constanza Celedón and Wilfredo Gonzáles for their constructive comments. This research was funded by FONDECYT grant 1030821, and P02-051 ICM. BBVA 2004 Prize in Conservation Biology is also acknowledged

\section{LITERATURE CITED}

AGRAWAL AA, SY STRAUSS \& MJ STOUT (1999) Cost of induced responses and tolerance to herbivory in male and female components of wild radish. Evolution 53: 1093-1104.

ANDERSON VJ \& DD BRISKE (1995) Herbivoreinduced species replacement in grasslands: is it driven by herbivory tolerance or avoidance? Ecological Applications 5: 1014-1024.

ARMESTO J, MTK ARROYO \& C VILLAGRÁN (1980) Altitudinal distribution, cover and size structure of umbelliferous cushion plants in the high Andes of central Chile. Acta Oecologica, Oecologia Generalia 1: 327-332.

BERTNESS MD \& RM CALLAWAY (1994) Positive interactions in communities. Trends in Ecology and Evolution 9: 191-193.

BROOKER RW \& TV CALLAGHAN (1998) The balance between positive and negative plant interactions and its relationship to environmental gradients: a model. Oikos 81: 196-207.

BRUNO JF, JJ STACHOWICZ \& MD BERTNESS (2003) Inclusion of facilitation into ecological theory. Trends in Ecology and Evolution 18: 119-125.

CALLAWAY RM (1995) Positive interactions among plants. Botanical Review 61: 306-349.

CALLAWAY RM \& RW WALKER (1997) Competition and facilitation: a synthetic approach to interactions in plant communities. Ecology 78: 1958-1965.

CALLAWAY RM \& FI PUGNAIRE (1999) Facilitation in plant communities. In: Pugnaire FI \& F Valladares (eds) Handbook of functional plant ecology: 623648. Marcel Dekker Inc., New York, New York, USA.

CALLAWAY RM, RW BROOKER, P CHOLER, Z KIKVIDZE, CJ LORTIE, R MICHALET, L PAOLINI, FI PUGNAIRE, B NEWINGHAM, ET ASCHEHOUG, C ARMAS, D KIKODZE \& BJ COOK (2002) Positive interactions among alpine plants increase with stress. Nature 417: 844-848.

CAVIERES LA \& MTK ARROYO (1999) Soil seed banks in Phacelia secunda JF Gmelin (Hydrophyllaceae): altitudinal variation in the Andes of central Chile (33 degrees S). Revista Chilena de Historia Natural 72: $569-577$.
CAVIERES LA, A PEÑALOZA \& MTK ARROYO (2000) Altitudinal belts in the high-Andes of central Chile $\left(33^{\circ}\right)$. Revista Chilena de Historia Natural 73: 331344.

CAVIERES LA, A PEÑALOZA, C PAPIC \& M TAMBUTTI (1998) Efecto nodriza del cojín Laretia acaulis (Umbelliferae) en la zona altoandina de Chile central. Revista Chilena de Historia Natural 71: 337-347.

CAVIERES LA, EI BADANO, A SIERRA-ALMEIDA, S GÓMEZ-GONZÁLEZ \& MA MOLINAMONTENEGRO (2006) Positive interactions between alpine plant species and the nurse cushion Laretia acaulis do not increase with elevation in the Andes of central Chile. New Phytologist 169: 59-69

CHOLER P, R MICHALET \& RM CALLAWAY (2001) Facilitation and competition on gradients in alpine plant communities. Ecology 82: 3295-3308.

DiCASTRI F \& E HAJEK (1976) Bioclimatología de Chile. Ediciones de la Universidad Católica de Chile, Santiago, Chile. 129 pp.

FORBIS TA (2003) Seedling demography in an alpine ecosystem. American Journal of Botany 90: 11971206.

FOX GA (1993) Failure-time analysis: emergence, flowering, survivorship and other waiting times. In: Scheiner SM \& J Gurevitch (eds) Design and analysis of ecological experiments: 253284.Chapman \& Hall, New York, New York, USA.

FRANCO AC \& PS NOBEL (1988) Interactions between seedlings of Agave deserti and the nurse plant Hilaria rigida. Ecology 69: 1731-1740.

FRANCO AC \& PS NOBEL (1989) Effect of nurse plants on the microhabitat and growth of cacti. Journal of Ecology 77: 870-886

GÓMEZ-APARICIO L, R ZAMORA, JM GÓMEZ, JA HÓDAR, J CASTRO \& E BARAZA (2004) Applying plant facilitation to forest restoration: a meta-analysis of the use of shrubs as nurse plants. Ecological Applications 14: 1128-1138.

HAMBACK PA, J AGREN \& L ERICSON (2000) Associational resistance: Insect damage to purple loosestrife reduced in thickets of sweet gale. Ecology 81: 1784-1794.

HARMS KE \& JW DALLING (1997) Damage and herbivory tolerance through resprouting as an advantage of large seed size in tropical trees and lianas. Journal of Tropical Ecology 13: 617-621.

HAY M (1986) Associational plant defenses and the maintenance of species diversity: turning competitors into accomplices. American Naturalist 128: 617-641.

HJÄLTÈN J \& PW PRICE (1997) Can plants gain protection from herbivory by association with unpalatable neighbors? a field experiment in a willow-sawfly system. Oikos 78: 317-322.

HULME PE (1996) Herbivory, plant regeneration, and species coexistence. Journal of Ecology 84: 609615.

IBÁÑEZ I \& EW SCHUPP (2001) Positive and negative interactions between environmental conditions affecting Cercocarpus ledifolius seedling survival. Oecologia 129: 543-550.

KAITANIEMI P, S NEUVONEN \& T NYYSSÖNEN (1999) Effects of cumulative defoliation on growth, reproduction, and insect resistance in mountain birch. Ecology 80: 524-532.

KARBAN R \& S THALER (1999) Plant phase change and resistance to herbivory. Ecology 80: 510-517.

LORTIE CJ, RW BROOKER, P CHOLER, Z KIKVIDZE, 
$R$ MICHALET, FI PUGNAIRE \& RM CALLAWAY (2004) Rethinking plant community theory. Oikos 107: 433-438.

MAESTRE FT, S BAUTISTA \& J CORTINA (2003) Positive, negative and net effects in grass-shrub interactions in Mediterranean semiarid grassland. Ecology 84: 3186-3197.

NABESHIMA E, M MURAKAMI \& T HIURA (2001) Effects of herbivory and light conditions on induced defense in Quercus crispula. Journal of Plant Research 114: 403-409.

NOWAK RS \& MM CALDWELL (1984) A test of compensatory photosynthesis in the field: implications for herbivory tolerance. Oecologia 61: 311-318.

PUGNAIRE FI \& MT LUQUE (2001) Changes in plant interactions along a gradient of environmental stress. Oikos 93: 42-49.

RADA F, FA SQUEO, A AZÓCAR \& HM CABRERA (1999) Water and Carbon Relations in the genus Adesmia (Papilionaceae) at different altitudes in the high north-central Chilean Andes. Revista Chilena de Historia Natural 72: 201-211.

RAND TA (2004) Competition, facilitation, and compensation for insect herbivory in an annual salt marsh forb. Ecology 85: 2046-2052.

ROUSSET O \& J LEPART (2000) Positive and negative interactions at different life stages of a colonizing species (Quercus humilis). Journal of Ecology 88: 401-412.

SANTIBÁÑEZ F \& JM URIBE (1990) Atlas agroclimático de Chile. Regiones V y Metropolitana. Ediciones Universidad de Chile, Facultad de Ciencias Agrarias y Forestales, Santiago, Chile. 103 pp.

SCHENK HJ \& BE MAHALL (2002) Positive and negative plant interactions contribute to a northsouth-patterned association between two desert shrub species. Oecologia 132: 402-410.

SHUMWAY SW (2000) Facilitative effects of a sand dune shrub on species growing beneath the shrub canopy. Oecologia 124: 138-148.
STILING P, AM ROSSI \& MV CATELL (2003) Associational resistance mediated by natural enemies. Ecological Entomology 28: 587-592.

STRAUSS SY (1991) Direct, indirect and cumulative effects of three native herbivores on a shared host plant. Ecology 72: 543-558.

STRAUSS SY \& AA AGRAWAL (1999) The ecology and evolution of plant tolerance to herbivory, Trends in Ecology and Evolution 14: 179-185.

STRAUSS SY, W WATSON \& MT ALLEN (2003) Predictors of male and female tolerance to insect herbivory in Raphanus raphanistrum. Ecology 84: 2074-2082.

TAHVANAINEN JO \& RB ROOT (1972) The influence of vegetational diversity on the population ecology of a specialized herbivore, Phyllotreta cruciferae (Coleoptera:Chrysomelidae). Oecologia 10:321346.

TEWKSBURY JJ \& JD LLOYD (2001) Positive interactions under nurse-plants: spatial scale, stress gradient and benefactor size. Oecologia 127: 425 424.

TIFFIN P (2000) Mechanisms of tolerance to herbivory damage: what do we know? Evolutionary Ecology 14: 523-536.

TIFFIN P \& BD INOUYE (2000) Measuring tolerance to herbivory: Accuracy and precision of estimates made using natural versus imposed damage. Evolution 54: 1024-1029.

THOMPSON VP, SA CUNNINGHAM, MC BALL \& AB NICOTRA (2003) Compensation for herbivory by Cucumis sativus trough increased photosynthetic capacity and efficiency. Oecologia 134: 167-175.

WELTER SC \& JW STEGGALL (1993) Contrasting the tolerance of wild and domesticated tomatoes to herbivory: agroecological implications. Ecological Applications 2: 271-278.

WISE MJ \& WG ABRAHAMSON (2005) Beyond the compensatory continuum: environmental resource levels and plant tolerance of herbivory. Oikos 109: 417-428. 